\title{
Reversed-Phase Column Extractive Separation of Gd(III) with Poly[dibenzo-18-crown-6]
}

\author{
K. R. Mahanwar, ${ }^{1}$ S. R. Sabale, ${ }^{1,2}$ R. B. Kadam, ${ }^{1}$ and B. S. Mohite ${ }^{1}$ \\ ${ }^{1}$ Analytical and Environmental Research Lab, Departnment of Chemistry, Shivaji University, Kolhapur 416004 (MS), India \\ ${ }^{2}$ Department of Chemistry, Jaysingpur College, Jaysingpur 416101, India
}

Correspondence should be addressed to S. R. Sabale, sandip_ana@rediffmail.com and B. S. Mohite, bsmohite@hotmail.com

Received 12 November 2011; Accepted 6 February 2012

Academic Editor: Karl Kirchner

Copyright ( $\odot 2012$ K. R. Mahanwar et al. This is an open access article distributed under the Creative Commons Attribution License, which permits unrestricted use, distribution, and reproduction in any medium, provided the original work is properly cited.

A poly[dibenzo-18-crown-6] exhibits good chemical stability, reusability and faster rate equilibrium for the separation of Gd(III). Both uptake and stripping of metal ions were rapid, indicating a better accessibility of the complexing sites. The proposed method has been applied for chromatographic separation of Gd(III) by using picric acid as medium and poly[dibenzo-18crown-6] as stationary phase. The influences of picric acid concentration, different eluting agents, and so forth, were discussed and the optimum condition were established. The breakthrough capacity of poly[dibenzo-18-crown-6] for Gd(III) was $0.572 \pm$ $0.01 \mathrm{mmolg}^{-1}$ of crown polymer. The proposed method has been applied to sequential chromatographic separation of their binary and multicomponent mixtures. Gd(III) has been determined from real samples with good analytical reliability.

\section{Introduction}

In recent years the separation chemistry of rare earth elements (REEs) continues to receive a growing interest. The major reasons for this stems from the importance of rare earths not only in industrial application but also in energy generation activities and environmental mitigation. Gadolinium is useful in nuclear techniques, in fuel element fabrication and in ceramic industries and as control rod and as refractory material $[1,2]$. In view of all the above applications the separation and purification of $\mathrm{Gd}(\mathrm{III})$ are important.

The main focus of the extensive research on chelating resins is the preparation of functionalized polymer that can provide more flexible working conditions together with good stability, selectivity, high concentrating ability, high capacity of metal ions, and simpler operation [3-6].

Crown ethers are effective extractants due to their ability to form stable complexes with metal ions. In recent years extraction chromatography has emerged as a versatile and effective method for analytical and preparative scale metal ion separation [7-9]. Also crown ethers are used as sorbents in chromatographic techniques [10-17] like TLC, extraction chromatography-liquid chromatography on columns, and gas chromatography for actinides and lanthanides.

By using poly[dibenzo-18-crown-6] we have reported the sorption behavior and separation study of alkali and alkaline earth metal in various mediums like ascorbic acid, sodium nitrate, hydrochloric acid, and L-arginine [18-23].

To our knowledge no successful attempts were reported in the literature for the separation of $\mathrm{Gd}(\mathrm{III})$ using poly[dibenzo-18-crown-6] in picric acid media and column chromatography. The present paper describes a simple and sensitive method for the determination of $\mathrm{Gd}(\mathrm{III})$ using poly[dibenzo-18-crown-6] as stationary phase in picric acid media. In our study we use picric acid as medium because picrate is bulkier anion with higher hydrophobicity. The proposed method has been successfully applied for the separation and determination of $\mathrm{Gd}(\mathrm{III})$ from real materials.

\section{Experimental}

2.1. Apparatus and Reagents. All absorbance measurements were carried out using a digital visible spectrophotometer (215 D, Thermo Electron LLS, India), a digital pH meter 
TABLE 1: Sorption of gadolinium(III) as a function of picric acid concentration (Gd(III): $100 \mu \mathrm{gmL}^{-1}$, eluent: $4.0 \mathrm{M} \mathrm{HCl}$ ).

\begin{tabular}{lc}
\hline $\begin{array}{l}\text { Picric acid concentration } \\
\left(\text { Mole L } \mathrm{L}^{-1}\right)\end{array}$ & $\begin{array}{c}\text { Sorption of gadolinium(III) } \\
(\%)\end{array}$ \\
\hline $1 \times 10^{-2}$ & 100 \\
$1 \times 10^{-3}$ & 100 \\
$1 \times 10^{-4}$ & 100 \\
$1 \times 10^{-5}$ & 97.4 \\
$1 \times 10^{-6}$ & 95.4 \\
$1 \times 10^{-7}$ & 90.2 \\
\hline
\end{tabular}

(Model LI-120. Elico, India) equipped with glass and a calomel electrode for $\mathrm{pH}$ determination, and a digital flame photometer (PI, Model no. 041, India).

A stock solution of $\mathrm{Gd}(\mathrm{III})$ was prepared by dissolving $1.091 \mathrm{~g}$ of gadolinium nitrate (AnalR grade, $\mathrm{BDH}$, Poole, $\mathrm{UK})$ in $100 \mathrm{~mL}$ of distilled deionised water and standardized gravimetrically [24]. A solution containing $100 \mu \mathrm{gmL}^{-1}$ of Gd(III) was prepared by appropriate dilution of the standard stock solution. Picric acid solution $\left(5 \times 10^{-2}\right.$ moleL $\left.^{-1}\right)$ was prepared by dissolving $2.846 \mathrm{~g}$ of picric acid in distilled deionised water and diluted to $250 \mathrm{~mL}$. All aqueous solutions were prepared with double distilled deionised water.

Poly[dibenzo-18-crown-6] from Merck Darmstadt, Germany was used after screening to 100-200 mesh. A total of $0.5 \mathrm{~g}$ of polymer was slurred with distilled deionised water and poured into a Pyrex glass chromatographic column $(20 \times 0.8 \mathrm{~cm}$ i.d. $)$. The column was used after preconditioning with picric acid solution. All chemicals used are of analytical grade.

2.2. General Procedure. $100 \mu \mathrm{g}$ of Gd(III) was mixed with picric acid solution in concentration range of $1 \times 10^{-2}$ to $1 \times 10^{-7} \mathrm{moleL}^{-1}$ in a total volume of $10 \mathrm{~mL}$. Then, the solution was passed through poly[dibenzo-18-crown-6] column preconditioned with the same concentration of picric acid as that of the sample solution at flow rate of 0.5 $\mathrm{mLmin}^{-1}$. Afterwards the column was washed with the same concentration of picric acid, and the sorbed Gd(III) was then eluted with different eluting agents at the flow rate of $0.5 \mathrm{mLmin}^{-1}$. $5.0 \mathrm{~mL}$ fractions were collected and analyzed spectrophotometrically with Arsenazo(III) $[25,26]$ at $650 \mathrm{~nm}$. The concentration of Gd(III) was calculated from a calibration graph.

\section{Results and Discussion}

3.1. Sorption of Gadolinium(III) on Poly [dibenzo-18-crown-6] as a Function of Picric Acid Concentration. Sorption studies of $\mathrm{Gd}(\mathrm{III})$ were carried out from picric acid medium using $100 \mu \mathrm{gmL}^{-1}$ of $\mathrm{Gd}(\mathrm{III})$. The concentration of picric acid was varied from $1 \times 10^{-2}$ to $1 \times 10^{-7} \mathrm{moleL}^{-1}$. It was found that there is quantitative sorption of $\mathrm{Gd}(\mathrm{III})$ from $1 \times 10^{-2}$ to $1 \times 10^{-4} \mathrm{moleL}^{-1}$ picric acid as shown in Table 1 . Sorbed $\mathrm{Gd}$ (III) was eluted with 4.0 M HCl. With further decrease in

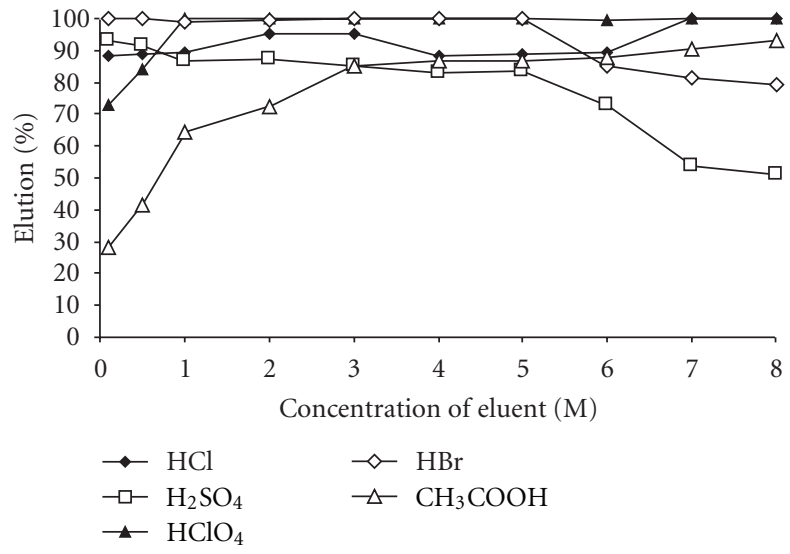

FIGURE 1: Elution study of $\mathrm{Gd}(\mathrm{III})$ with various eluents. Eluents used such as $\mathrm{HCl}, \mathrm{H}_{2} \mathrm{SO}_{4}, \mathrm{HClO}_{4}, \mathrm{HBr}, \mathrm{CH}_{3} \mathrm{COOH}$ out of this 2.0 8.0 M HCl, 0.1-0.5 $\mathrm{M} \mathrm{H}_{2} \mathrm{SO}_{4}, 1.0-8.0 \mathrm{M} \mathrm{HClO}_{4}, 0.1-5.0 \mathrm{M} \mathrm{HBr}$ and 7.0-8.0 $\mathrm{M} \mathrm{CH}_{3} \mathrm{COOH}$ were efficient eluting agent for $\mathrm{Gd}(\mathrm{III})$.

the concentration of picric acid the sorption of gadolinium also decreases. The subsequent sorption studies of $\mathrm{Gd}(\mathrm{III})$ were carried out with $1 \times 10^{-3}$ moleL $^{-1}$ picric acid.

3.2. Elution Studies of Gadolinium(III) with Various Eluting Agents. Gd(III) was eluted out from the column with different strengths of acids such as $\mathrm{HCl}, \mathrm{H}_{2} \mathrm{SO}_{4}, \mathrm{HClO}_{4}$, $\mathrm{CH}_{3} \mathrm{COOH}$, and $\mathrm{HBr}$. The concentrations of the eluting agents were varied from 0.1 to $8.0 \mathrm{M}$. Gadolinium(III) was eluted quantitatively with $2.0-8.0 \mathrm{M} \mathrm{HCl}, 0.1-0.5 \mathrm{M} \mathrm{H}_{2} \mathrm{SO}_{4}$, 1.0-8.0 $\mathrm{M} \mathrm{HClO}_{4}, 7.0-8.0 \mathrm{M} \mathrm{CH} \mathrm{CH}_{3} \mathrm{COOH}$, and $0.1-5.0 \mathrm{M}$ $\mathrm{HBr}$. Further, the elution study of Gd(III) in this work was carried out with $0.1 \mathrm{M} \mathrm{HBr}$. The elution profile of Gd(III) with different eluting agents is shown in Figure 1.

3.3. Breakthrough Capacity of Poly[dibenzo-18-crown-6]. The breakthrough capacity of $\mathrm{Gd}(\mathrm{III})$ was carried out on $1.0 \mathrm{~g}$ of poly[dibenzo-18-crown-6] with $1 \times 10^{-3} \mathrm{moleL}^{-1}$ picric acid. The volume of Gd(III) sample solution employed was $10.0 \mathrm{~mL}$. The concentration of Gd(III) was varied from 100 to $1100 \mu \mathrm{g}$ of $\mathrm{Gd}(\mathrm{III}) 10 \mathrm{~mL}^{-1}$ of solution. After sorption, the elution of $\mathrm{Gd}(\mathrm{III})$ was carried out with $0.1 \mathrm{M} \mathrm{HBr}$ at a flow rate of $0.5 \mathrm{~mL} \mathrm{~min}^{-1}$. Sorption of $\mathrm{Gd}(\mathrm{III})$ was quantitative up to $900 \mu \mathrm{g} 10 \mathrm{~mL}^{-1}$. The extent of sorption of $\mathrm{Gd}(\mathrm{III})$ is decreased with the increase in the concentration of Gd(III) as shown in Figure 2. The breakthrough capacity of poly[dibenzo-18-crown-6] for Gd(III) was found to be 0.57 $\mathrm{mmolg}^{-1}$ of crown polymer.

3.4. Diverse Ion Effect. To assess the usefulness of this method, the effects of foreign ions, which are likely to interfere with the proposed method for determination of Gd(III) were studied. An aliquot of solution containing $100 \mu \mathrm{g}$ of $\mathrm{Gd}$ (III) was mixed with foreign ions and picric acid was added so that its concentration was $1 \times 10^{-3} \mathrm{moleL}^{-1}$ in total volume of $10 \mathrm{~mL}$. The tolerance limit was set not to cause more than $\pm 2 \%$ deviation in the recovery of $\mathrm{Gd}$ (III). 
TABle 2: Diverse ion effect (Gd(III): $100 \mu \mathrm{gmL}^{-1}$, sorption: $1 \times 10^{-3} \mathrm{M}$ picric acid, eluent: $0.5 \mathrm{M} \mathrm{HCl}$ ).

\begin{tabular}{|c|c|c|c|c|c|}
\hline Ion & Added as & Tol. limit (mg) & Ion & Added as & Tol. limit (mg) \\
\hline $\mathrm{Li}^{+}$ & $\mathrm{LiCl}$ & 4 & $\mathrm{Al}^{3+}$ & $\mathrm{Al}_{2}\left(\mathrm{SO}_{4}\right)_{3} \cdot 16 \mathrm{H}_{2} \mathrm{O}$ & 0.5 \\
\hline $\mathrm{Na}^{+}$ & $\mathrm{NaCl}$ & 4 & $\mathrm{Zr}^{4+}$ & $\mathrm{Zr}\left(\mathrm{NO}_{3}\right)_{4} \cdot 4 \mathrm{H}_{2} \mathrm{O}$ & 1 \\
\hline $\mathrm{K}^{+}$ & $\mathrm{KCl}$ & 2 & $\mathrm{La}^{3+}$ & $\mathrm{La}\left(\mathrm{NO}_{3}\right)_{3}$ & 0.8 \\
\hline $\mathrm{Rb}^{+}$ & $\mathrm{RbCl}$ & 5 & $\mathrm{Ce}^{3+}$ & $\mathrm{CeCl}_{2} \cdot 6 \mathrm{H}_{2} \mathrm{O}$ & 0.2 \\
\hline $\mathrm{Cs}^{+}$ & $\mathrm{CsCl}$ & 4 & $\mathrm{~V}^{4+}$ & $\mathrm{VOSO}_{4} \cdot 4 \mathrm{H}_{2} \mathrm{O}$ & 0.4 \\
\hline $\mathrm{NH}_{4}^{+}$ & $\mathrm{NH}_{4} \mathrm{Cl}$ & 4 & $\mathrm{Th}^{4+}$ & $\mathrm{Th}\left(\mathrm{NO}_{3}\right)_{4}$ & 0.2 \\
\hline $\mathrm{Be}^{2+}$ & $\mathrm{BeSO}_{4} \cdot 4 \mathrm{H}_{2} \mathrm{O}$ & 0.1 & $\mathrm{Mo}^{6+}$ & $\left(\mathrm{NH}_{4}\right)_{6} \mathrm{Mo}_{7} \mathrm{O}_{24} 4 \mathrm{H}_{2} \mathrm{O}$ & 0.9 \\
\hline $\mathrm{Ca}^{2+}$ & $\mathrm{CaCl}_{2}$ & 0.4 & $\mathrm{~W}^{6+}$ & $\mathrm{Na}_{2} \mathrm{WO}_{4} \cdot 4 \mathrm{H}_{2} \mathrm{O}$ & 0.8 \\
\hline $\mathrm{Sr}^{2+}$ & $\mathrm{Sr}\left(\mathrm{NO}_{3}\right)_{2}$ & 0.5 & $\mathrm{U}^{6+}$ & $\mathrm{UO}_{2}\left(\mathrm{NO}_{3}\right)_{2} \cdot 6 \mathrm{H}_{2} \mathrm{O}$ & 0.5 \\
\hline $\mathrm{Ba}^{2+}$ & $\mathrm{Ba}\left(\mathrm{NO}_{3}\right)_{2}$ & 0.3 & $\mathrm{Cl}^{-}$ & $\mathrm{HCl}$ & 3 \\
\hline $\mathrm{Co}^{2+}$ & $\mathrm{CoCl}_{2} \cdot 6 \mathrm{H}_{2} \mathrm{O}$ & 8 & $\mathrm{Br}^{-}$ & $\mathrm{HBr}$ & 4 \\
\hline $\mathrm{Ni}^{2+}$ & $\mathrm{NiCl}_{2} \cdot 6 \mathrm{H}_{2} \mathrm{O}$ & 0.8 & $\mathrm{SCN}^{-}$ & $\mathrm{NaSCN}$ & 1 \\
\hline $\mathrm{Mn}^{2+}$ & $\mathrm{MnCl}_{2} \cdot 4 \mathrm{H}_{2} \mathrm{O}$ & 2 & $\mathrm{ClO}_{4}^{-}$ & $\mathrm{HClO}_{4}$ & 5 \\
\hline $\mathrm{Zn}^{2+}$ & $\mathrm{ZnCl}_{2}$ & 0.5 & $\mathrm{CH}_{3} \mathrm{COO}^{-}$ & $\mathrm{CH}_{3} \mathrm{COOH}$ & 5 \\
\hline $\mathrm{Cd}^{2+}$ & $\left(\mathrm{CH}_{3} \mathrm{COO}\right)_{2} \mathrm{Cd} \cdot \mathrm{H}_{2} \mathrm{O}$ & 3 & $\mathrm{SO}_{4}^{2-}$ & $\mathrm{H}_{2} \mathrm{SO}_{4}$ & 0.8 \\
\hline $\mathrm{Pb}^{2+}$ & $\mathrm{Pb}\left(\mathrm{NO}_{3}\right)_{2}$ & 1 & Tartrate & Tartaric acid & 4 \\
\hline $\mathrm{Cr}^{3+}$ & $\mathrm{Cr}\left(\mathrm{NO}_{3}\right)_{3} \cdot 9 \mathrm{H}_{2} \mathrm{O}$ & 0.5 & EDTA & EDTA & 4 \\
\hline $\mathrm{Fe}^{3+}$ & $\mathrm{FeCl}_{3} \cdot 6 \mathrm{H}_{2} \mathrm{O}$ & 0.1 & Ascorbate & Ascorbic acid & 4 \\
\hline $\mathrm{Cu}^{2+}$ & $\mathrm{CuCl}_{2}$ & 0.8 & Citrate & Citric acid & 4 \\
\hline
\end{tabular}

TABLE 3: Separation of gadolinium(III) from associated elements (multicomponent mixture).

\begin{tabular}{|c|c|c|c|c|c|}
\hline Sr. no. & Mixture & Taken $(\mu \mathrm{g})$ & Recovery* (\%) & S.D. & Eluent \\
\hline \multirow{4}{*}{1} & $\mathrm{Fe}(\mathrm{II})$ & 100 & 98.16 & \pm 0.28 & $\mathrm{NSPC}^{* *}$ \\
\hline & $\mathrm{U}(\mathrm{VI})$ & 100 & 98.78 & \pm 0.25 & $0.2 \mathrm{M} \mathrm{LiOH}$ \\
\hline & Gd(III) & 100 & 98.83 & \pm 0.06 & $2.0 \mathrm{M} \mathrm{HClO}_{4}$ \\
\hline & $\mathrm{Ba}(\mathrm{II})$ & 100 & 97.94 & \pm 0.18 & $4.0 \mathrm{M} \mathrm{HCl}$ \\
\hline \multirow{4}{*}{2} & $\mathrm{Ca}(\mathrm{II})$ & 100 & 100 & \pm 0.56 & NSPC $^{* *}$ \\
\hline & $\mathrm{U}(\mathrm{VI})$ & 100 & 97.76 & \pm 0.87 & $0.2 \mathrm{M} \mathrm{LiOH}$ \\
\hline & Gd(III) & 100 & 100 & \pm 0.01 & $2.0 \mathrm{M} \mathrm{HClO}_{4}$ \\
\hline & $\mathrm{Ba}(\mathrm{II})$ & 100 & 98 & \pm 0.87 & $4.0 \mathrm{M} \mathrm{HCl}$ \\
\hline \multirow{4}{*}{3} & $\mathrm{Li}(\mathrm{I})$ & 100 & 99 & \pm 0.26 & $\mathrm{NSPC}^{* *}$ \\
\hline & $\mathrm{U}(\mathrm{VI})$ & 100 & 99 & \pm 0.94 & $0.2 \mathrm{M} \mathrm{LiOH}$ \\
\hline & Gd(III) & 100 & 98.6 & \pm 0.66 & $2.0 \mathrm{M} \mathrm{HClO}_{4}$ \\
\hline & $\mathrm{Ba}(\mathrm{II})$ & 100 & 98.10 & \pm 0.06 & $4.0 \mathrm{M} \mathrm{HCl}$ \\
\hline \multirow{4}{*}{4} & $\mathrm{Mg}(\mathrm{II})$ & 100 & 98.4 & \pm 0.55 & NSPC** \\
\hline & $\mathrm{U}(\mathrm{VI})$ & 100 & 98 & \pm 0.10 & $0.2 \mathrm{M} \mathrm{LiOH}$ \\
\hline & Gd(III) & 100 & 100 & \pm 0.41 & $2.0 \mathrm{M} \mathrm{HClO}_{4}$ \\
\hline & $\mathrm{Ba}(\mathrm{II})$ & 100 & 97.5 & \pm 0.62 & $4.0 \mathrm{M} \mathrm{HCl}$ \\
\hline \multirow{4}{*}{5} & $\mathrm{Mo}(\mathrm{II})$ & 100 & 99.1 & \pm 0.54 & $\mathrm{NSPC}^{* *}$ \\
\hline & $\mathrm{U}(\mathrm{VI})$ & 100 & 98.6 & \pm 0.50 & $0.2 \mathrm{M} \mathrm{LiOH}$ \\
\hline & Gd(III) & 100 & 99.2 & \pm 0.30 & $2.0 \mathrm{M} \mathrm{HClO}_{4}$ \\
\hline & $\mathrm{Ba}(\mathrm{II})$ & 100 & 97.3 & \pm 0.61 & $4.0 \mathrm{M} \mathrm{HCl}$ \\
\hline \multirow{4}{*}{6} & $\mathrm{Sr}(\mathrm{II})$ & 100 & 98.9 & \pm 0.07 & $\mathrm{NSPC}^{* *}$ \\
\hline & $\mathrm{U}(\mathrm{VI})$ & 100 & 98 & \pm 0.94 & $0.2 \mathrm{M} \mathrm{LiOH}$ \\
\hline & Gd(III) & 100 & 99 & \pm 0.65 & $2.0 \mathrm{M} \mathrm{HClO}_{4}$ \\
\hline & $\mathrm{Ba}(\mathrm{II})$ & 100 & 97.92 & \pm 0.06 & $4.0 \mathrm{M} \mathrm{HCl}$ \\
\hline
\end{tabular}

* Average of triplicate analysis.

** No sorption passing through the column. 
TABLE 4: Reproducibility of the method.

\begin{tabular}{|c|c|c|c|}
\hline Sr. no. & Gd(III) $100 \mu \mathrm{g}$ & Recovery \% & S.D \\
\hline 1 & 100 & 99.9 & 0.010 \\
\hline 2 & 100 & 99.9 & 0.069 \\
\hline 3 & 100 & 98.9 & 0.005 \\
\hline 4 & 100 & 99.2 & 0.032 \\
\hline 5 & 100 & 99 & 0.014 \\
\hline 6 & 100 & 99.3 & 0.010 \\
\hline 7 & 100 & 98.9 & 0.032 \\
\hline 8 & 100 & 99.6 & 0.062 \\
\hline 9 & 100 & 99 & 0.015 \\
\hline 10 & 100 & 99.8 & 0.033 \\
\hline 11 & 100 & 99.8 & 0.047 \\
\hline 12 & 100 & 99.8 & 0.023 \\
\hline 13 & 100 & 99.6 & 0.010 \\
\hline 14 & 100 & 99 & 0.015 \\
\hline 15 & 100 & 99.8 & 0.037 \\
\hline 16 & 100 & 99.85 & 0.031 \\
\hline 17 & 100 & 99.92 & 0.060 \\
\hline 18 & 100 & 99.8 & 0.034 \\
\hline 19 & 100 & 98.75 & 0.010 \\
\hline 20 & 100 & 98.99 & 0.016 \\
\hline 21 & 100 & 99.96 & 0.011 \\
\hline 22 & 100 & 99.93 & 0.040 \\
\hline 23 & 100 & 98.8 & 0.015 \\
\hline 24 & 100 & 98.88 & 0.010 \\
\hline 25 & 100 & 99.9 & 0.010 \\
\hline 26 & 100 & 98.75 & 0.053 \\
\hline 27 & 100 & 98.89 & 0.016 \\
\hline 28 & 100 & 99 & 0.005 \\
\hline 29 & 100 & 99.36 & 0.008 \\
\hline 30 & 100 & 99.63 & 0.011 \\
\hline
\end{tabular}

The column was equilibrated with $1 \times 10^{-3} \mathrm{moleL}^{-1}$ picric acid, and binary mixture solution was passed through a poly [dibenzo-18-crown-6] column at flow rate of $0.5 \mathrm{mLmin}^{-1}$. Subsequently, the column was washed with $15 \mathrm{~mL}$ of $1 \times$ $10^{-3}$ moleL $^{-1}$ picric acid to remove unsorbed metal ions. Various foreign ions were not sorbed and hence passed through the column. The effluent was collected and analyzed for foreign ion content. It was found that most of alkali metals show high tolerance limits. The alkaline earth metals were sorbed quantitatively. Most of the p-block and dblock elements showed low tolerance limit. Amongst the inner transition elements U (VI) was sorbed along with Gd(III) and its separation is carried out in our subsequent study employing multicomponent mixtures. The anions of inorganic and organic acids have shown high tolerance limit except $\mathrm{SO}_{4}{ }^{2-}$. The tolerance limit of various foreign ions is shown in Table 2.

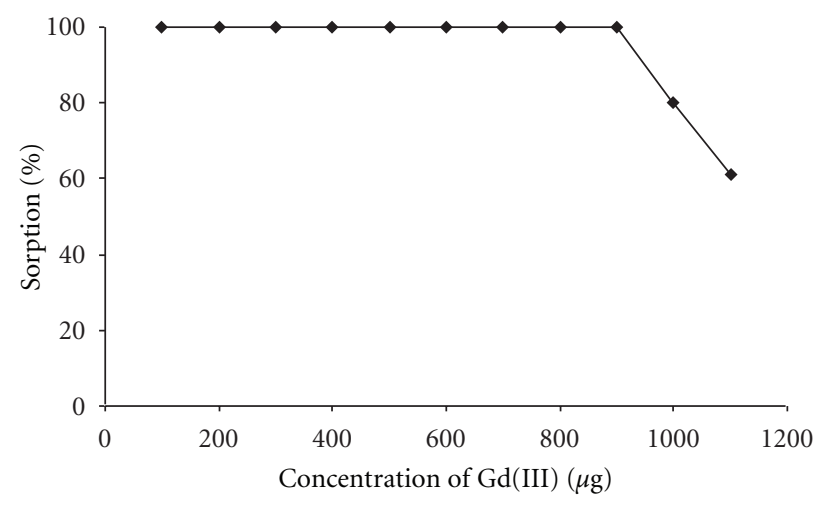

FIGURE 2: Effect of varying concentrations of Gd(III). The concentration of $\mathrm{Gd}(\mathrm{III})$ was varied from 100 to $1100 \mu \mathrm{g}$ of $\mathrm{Gd}(\mathrm{III})$ $10 \mathrm{~mL}^{-1}$ of solution. Sorption of Gd(III) was quantitative up to 900 $\mu \mathrm{g} 10 \mathrm{~mL}^{-1}$.

3.5. Separation of Gadolinium(III) from Multicomponent Mixtures. A mixture of $\mathrm{Li}(\mathrm{I}) / \mathrm{Fe}(\mathrm{III}) / \mathrm{Mo}(\mathrm{VI}) / \mathrm{Sr}(\mathrm{II}) / \mathrm{Ca}(\mathrm{II})$, $\mathrm{U}(\mathrm{VI}), \mathrm{Gd}(\mathrm{III})$, and $\mathrm{Ba}(\mathrm{II})$ was resolved by following the proposed procedure of $\mathrm{Gd}(\mathrm{III})$. The mixture was passed through the poly[dibenzo-18-crown-6] column under optimum condition of $\mathrm{Gd}(\mathrm{III})$, where $\mathrm{Li}(\mathrm{I}) / \mathrm{Fe}(\mathrm{III}) / \mathrm{Mo}(\mathrm{VI}) / \mathrm{Ca}(\mathrm{II}) / \mathrm{Sr}(\mathrm{II})$ was not sorbed and passed through column which was then determined by standard procedure $[24,26]$. U(VI) and $\mathrm{Ba}(\mathrm{II})$ were quantitatively sorbed on column along with Gd(III). The separation of Gd(III) from U(VI) can be achieved by the use of $0.2 \mathrm{M} \mathrm{LiOH}$ as a eluting agent; at this condition $\mathrm{Gd}(\mathrm{III})$ and $\mathrm{Ba}(\mathrm{II})$ was not eluted and remained on column. Gd(III) was eluted with $2.0 \mathrm{M}$ perchloric acid, and the remaining $\mathrm{Ba}$ (II) on column was eluted with $4.0 \mathrm{M}$ hydrochloric acid and determined by standard methods [24, 26]. The results are shown in Table 3 and chromatograms of all metal ions in Figure 3.

3.6. Reproducibility of the Method. Reproducibility of the method was checked by thirty replicate analyses of a standard Gd(III) solution. The results indicate the method to be fairly reproducible. The poly[dibenzo-18-crown-6] could be recycled many times without affecting its sorption capacity. The reusability of poly[dibenzo-18-crown-6] with standard deviations is shown in Table 4.

3.7. Determination of Gadolinium(III) from Real Samples. The composite material sample $\left(\mathrm{GdSrO}_{2}\right)$ after acid treatment is subjected to the proposed method for the determination of Gd(III). The percentage of Gd(III) found after triplicate analysis is $9.89( \pm 0.11)$ as against the reported value of $10.0 \%$.

\section{Conclusion}

The proposed method affords an attractive feature as compared to the solvent extraction technique, that is, it is free from any organic diluents, leading to potential green chemistry applications. It permits the separation of Gd(III) from 
Mixture 1

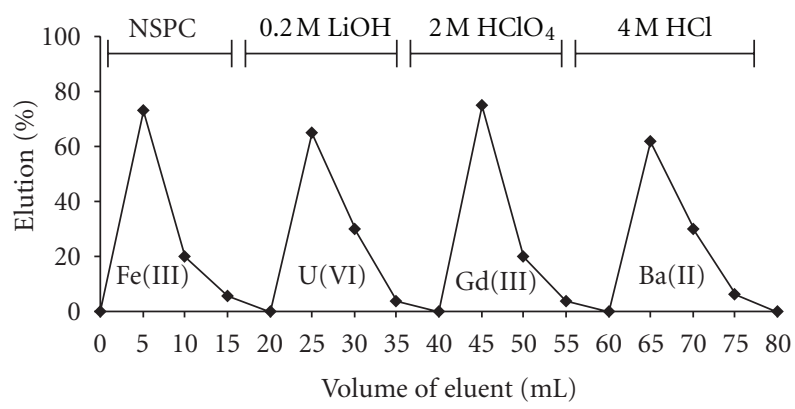

(a) Separation of Fe(III), U(VI), Gd(III), Ba(II)

Mixture 3

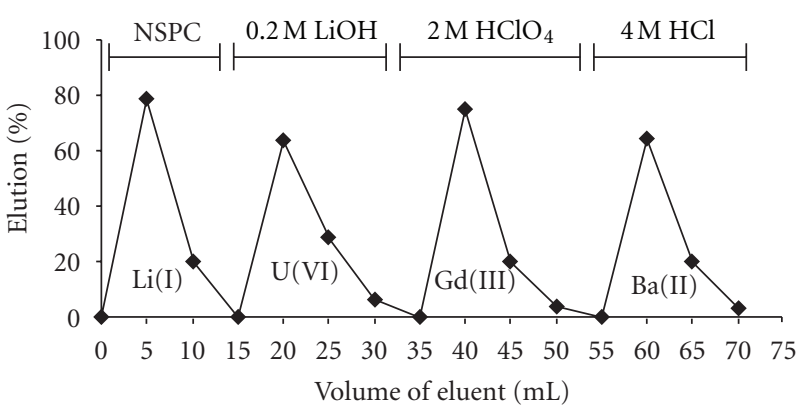

(c) Separation Li(I), U(VI), Gd(III), Ba(II)

Mixture 5

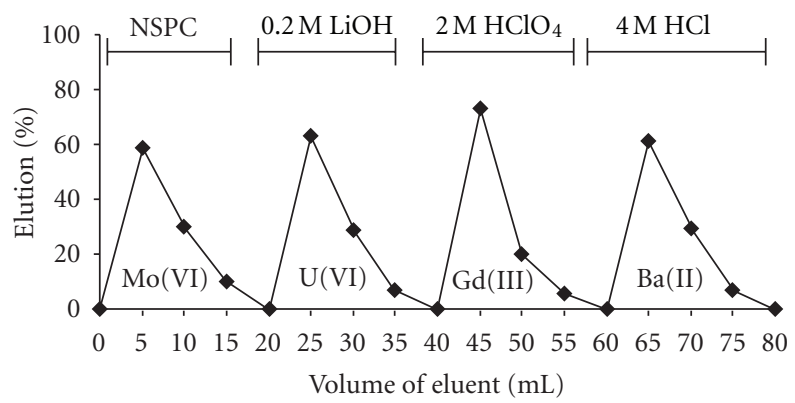

(e) Separation of Mo(VI), U(VI), Gd(III), Ba(II)
Mixture 2

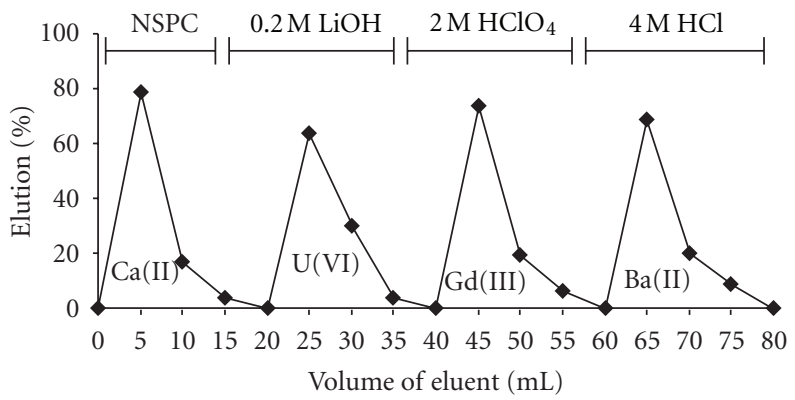

(b) Separation of $\mathrm{Ca}(\mathrm{II}), \mathrm{U}(\mathrm{VI}), \mathrm{Gd}(\mathrm{III}), \mathrm{Ba}(\mathrm{II})$

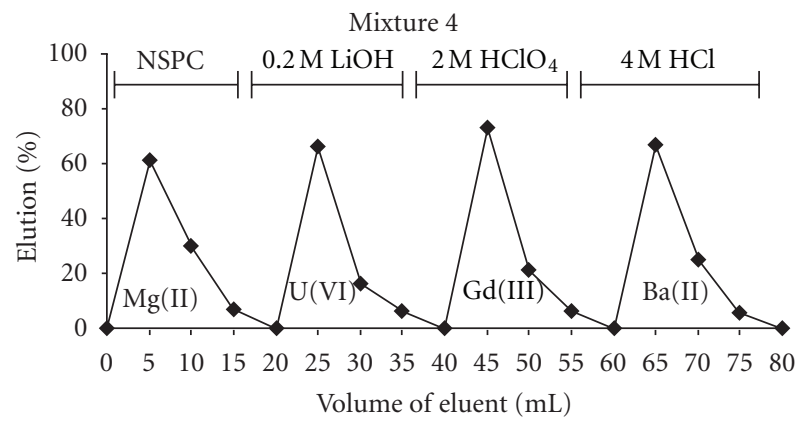

(d) Separation of $\mathrm{Mg}(\mathrm{II}), \mathrm{U}(\mathrm{VI}), \mathrm{Gd}(\mathrm{III}), \mathrm{Ba}(\mathrm{II})$

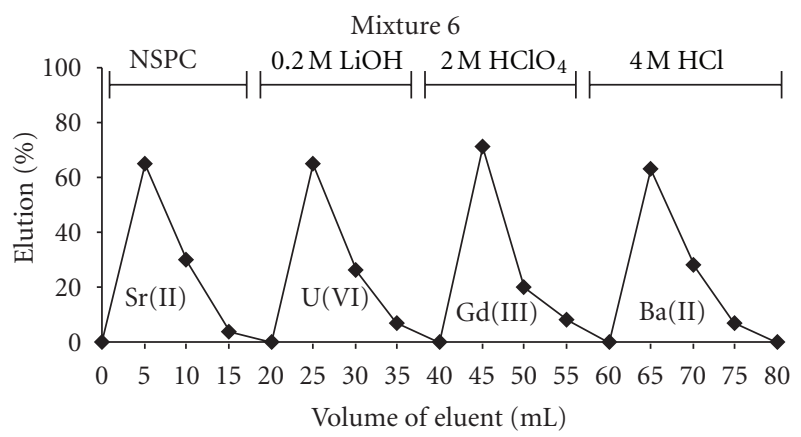

(f) Separation of Mo(VI), U(VI), Gd(III), Ba(II)

Figure 3: Chromatogram of Multicomponent Mixtures. Separation different metal ions such as U(VI), $\mathrm{Ba}(\mathrm{II}), \mathrm{Mo}(\mathrm{VI}), \mathrm{Ca}(\mathrm{II}), \mathrm{Sr}(\mathrm{II}), \mathrm{Mg}(\mathrm{II})$ from $\mathrm{Gd}(\mathrm{III})$.

nuclear fission products such as $\mathrm{Ba}(\mathrm{II}), \mathrm{U}(\mathrm{VI})$ and $\mathrm{Sr}(\mathrm{II})$ is the significant achievement of our work. The poly[dibenzo18-crown-6] could be recycled many times without affecting its sorption capacity, that is, it has higher stability as a stationary phase. Low reagent and acid concentrations are required for quantitative recovery of Gd(III). Precision in terms of the standard deviation of the present method is very retainable for the determination of $\mathrm{Gd}(\mathrm{III})$. It is applicable for the analysis of $\mathrm{Gd}(\mathrm{III})$ in real sample.

\section{References}

[1] P. Maestro and D. Huguenin, "Industrial applications of rare earths: which way for the end of the century," Journal of Alloys and Compounds, vol. 225, no. 1-2, pp. 520-528, 1995.
[2] J. Will, A. Mitterdorfer, C. Kleinlogel, D. Perednis, and L. J. Gauckler, "Fabrication of thin electrolytes for secondgeneration solid oxide fuel cells," Journal of Solid State Ionics, vol. 131, no. 1, pp. 79-96, 2000.

[3] C. Kantipuly, S. Katragadda, A. Chow, and H. D. Gesser, "Chelating polymers and related supports for separation and preconcentration of trace metals," Talanta, vol. 37, no. 5, pp. 491-517, 1990.

[4] C. J. Kantipuly and A. D. Westland, "Review of methods for the determination of lanthanides in geological samples," Talanta, vol. 35 , no. 1, pp. 1-13, 1988.

[5] G. V. Mgasoedova and S. B. Savvin, "Chelating sorbents in analytical chemistry," Critical Reviews in Analytical Chemistry, vol. 17, no. 1, pp. 1-63, 1986.

[6] A. Warshawsky, "Selective ion exchange polymers," Die Angewandte Makromolekulare Chemie, vol. 109, no. 1, pp. 171-196, 1982. 
[7] J. L. Cortina and A. Warshawsky, "Developments in solidliquid extraction by solvent impregnated resins," in Ion Exchange and Solvent Extraction, J. A. Marinsky and Y. Marcus, Eds., vol. 13, p. 195, Marcel Dekker, New York, NY, USA, 1997.

[8] A. Naim, Z. Hans, and M. B. Harry, "Strontium ion selective electrode based on a conducting poly(Dibenzo-18-Crown-6) film," Analytical Letters, vol. 24, no. 8, pp. 1431-1443, 1991.

[9] L. Angely, V. Questaigne, and J. Rault-Berthelot, "The influence of poly-dibenzo-crown ether treatments on their complexing properties: application to $\mathrm{Ag}^{+}$extraction," Synthetic Metals, vol. 52, no. 1, pp. 111-124, 1992.

[10] M. R. Shivade and V. M. Shinde, "Extraction of gadolinium with liquid ion-exchangers," Fresenius' Zeitschrift für Analytische Chemie, vol. 317, no. 7, p. 792, 1984.

[11] N. de Jong, M. Draye, A. Favre-Réguillon, G. LeBuzit, G. Cote, and J. Foos, "Lanthanum(III) and gadolinium(III) separation by cloud point extraction," Journal of Colloid and Interface Science, vol. 291, no. 1, pp. 303-306, 2005.

[12] J. E. Powell and H. R. Burkholder, "Augmenting the separation of gadolinium and europim and europium and samarium mixtures in ion exchange elutions with EDTA," Journal of Chromatography A, vol. 29, pp. 210-217, 1967.

[13] C. A. Morais and V. S. T. Ciminelli, "Selection of solvent extraction reagent for the separation of europium(III) and gadolinium(III)," Minerals Engineering, vol. 20, no. 8, pp. 747752, 2007.

[14] D. Nayak and S. Lahiri, "Extraction and separation of141Ce and153Gd with HDEHP," Journal of Radioanalytical and Nuclear Chemistry, vol. 240, no. 1, pp. 75-77, 1999.

[15] B. S. Mohite, C. D. Jadage, and S. R. Pratap, "Method for the extraction chromatographic separation of barium from other elements with dibenzo-18-crown-6," Analyst, vol. 115, no. 10, pp. 1367-1369, 1990.

[16] N. Y. Kremliakova, A. P. Novikov, and B. F. Myasoedov, "Extraction chromatographic separation of radionuclides of strontium, cesium and barium with the use of TVEXDCH18C6," Journal of Radioanalytical and Nuclear Chemistry, vol. 145, no. 1, pp. 23-28, 1990.

[17] E. P. Horwitz, M. L. Dietz, and D. E. Fisher, "Separation and preconcentration of strontium from biological, environmental, and nuclear waste samples by extraction chromatography using a crown ether," Analytical Chemistry, vol. 63, no. 5, pp. 522-525, 1991.

[18] B. S. Mohite and A. S. Jadhav, "Column chromatographic separation of uranium(VI) and other elements using poly(dibenzo-18-crown-6) and ascorbic acid medium," Journal of Chromatography A, vol. 983, no. 1-2, pp. 277-281, 2003.

[19] B. S. Mohite and A. S. Jadhav, "Column chromatographic separation of thorium(IV) from ascorbic acid medium using poly-(dibenzo-18-crown-6)," Journal of Radioanalytical and Nuclear Chemistry, vol. 256, no. 1, pp. 173-176, 2003.

[20] B. S. Mohite, J. M. Patil, and D. N. Zambare, "Column chromatographic separation of molybdenum (VI) from alloys with poly-(dibenzo-18-crown-6) from a hydrochloric acid medium," Talanta, vol. 40, no. 10, pp. 1511-1518, 1993.

[21] B. S. Mohlte, D. N. Zambare, and B. E. Mahadik, "Potassium Separation from S-Block and Other Elements Using a Polymeric Crown Ether," Analytical Chemistry, vol. 66, no. 22, pp. 4097-4099, 1994.

[22] B. S. Mohite, J. M. Patil, and D. N. Zambare, "Solvent extraction separation of uranium(VI) with dibenzo-24-crown-8," Journal of Radioanalytical and Nuclear Chemistry, vol. 170, no. 1, pp. 215-224, 1993.
[23] S. R. Sabale, D. V. Jadhav, and B. S. Mohite, "Sorption study of U(VI), Th(IV) and Ce(III) on poly[dibenzo-18-crown-6] in 1-arginine to develop sequential column chromatographic separation method," Journal of Radioanalytical and Nuclear Chemistry, vol. 284, no. 2, pp. 273-278, 2010.

[24] A. I. Vogel, A Textbook of Quantitative Inorganic Analysis, Longmans, London, UK, 3rd edition, 1975.

[25] Z. Marczenko, Spectrophotometer Determination of Elements, Ellis Horword Limited, Chichester, UK, 1976.

[26] V. P. Dedkova, O. P. Shvoeva, and S. B. Savvin, "Sorptionspectrometric determination of thorium(IV) and uranium(VI) with the reagent Arsenazo III on the solid phase of a fibrous material filled with a cation exchanger," Journal of Analytical Chemistry, vol. 63, no. 5, pp. 430-434, 2008. 


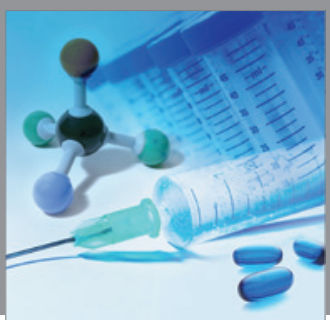

International Journal of

Medicinal Chemistry

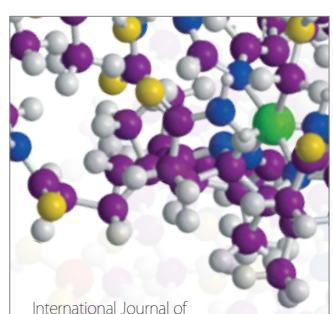

Carbohydrate Chemistry

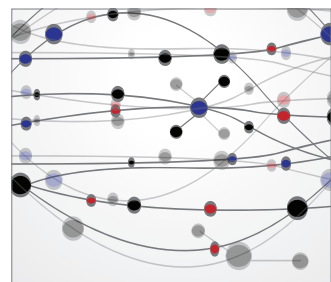

The Scientific World Journal
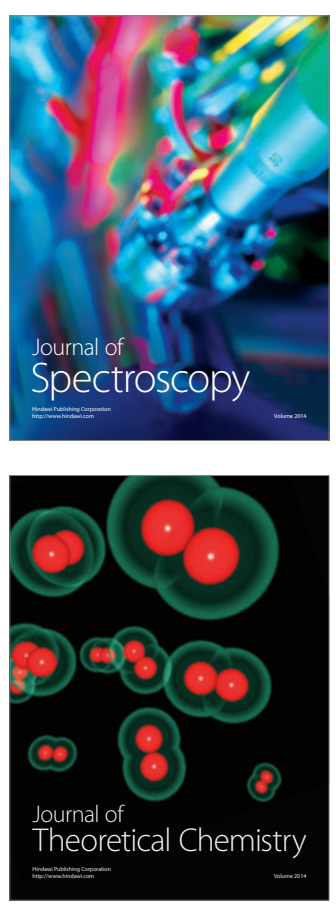
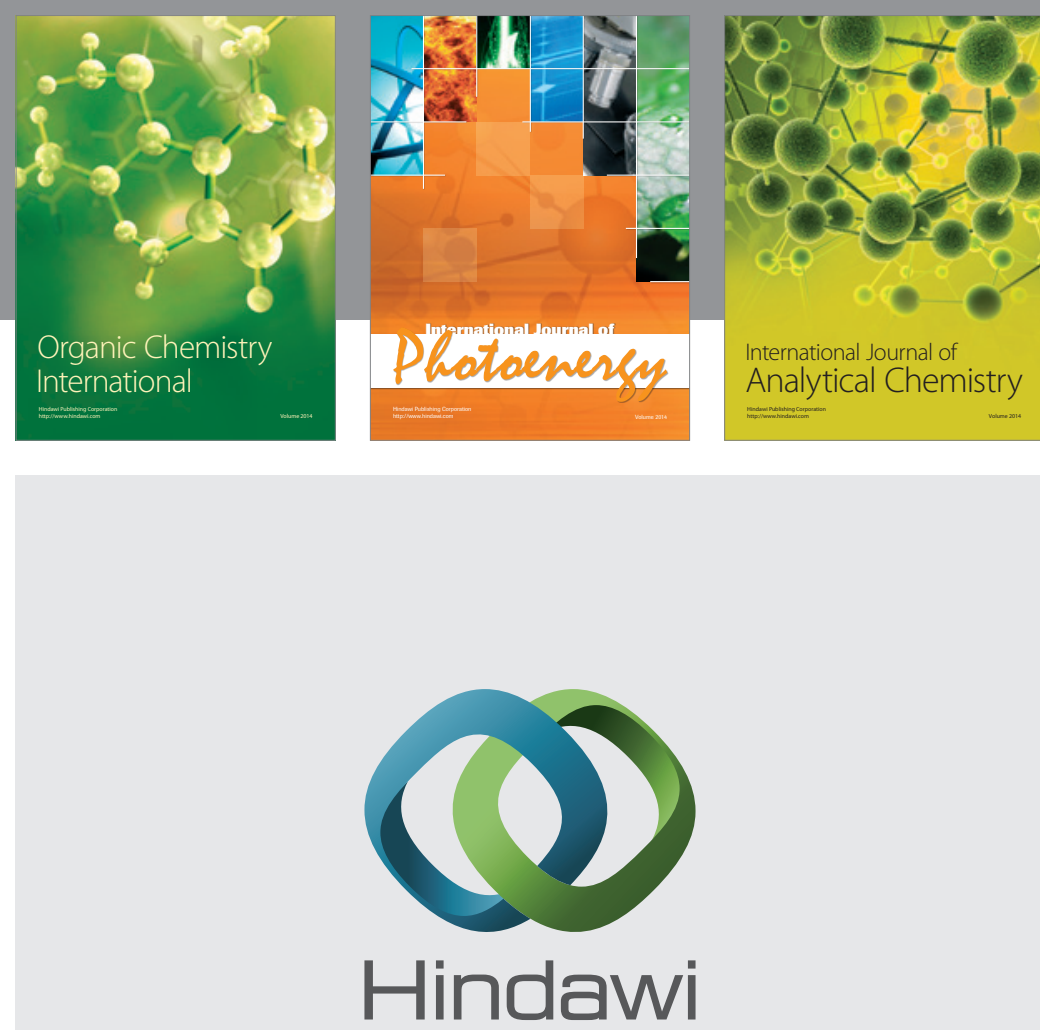

Submit your manuscripts at

http://www.hindawi.com
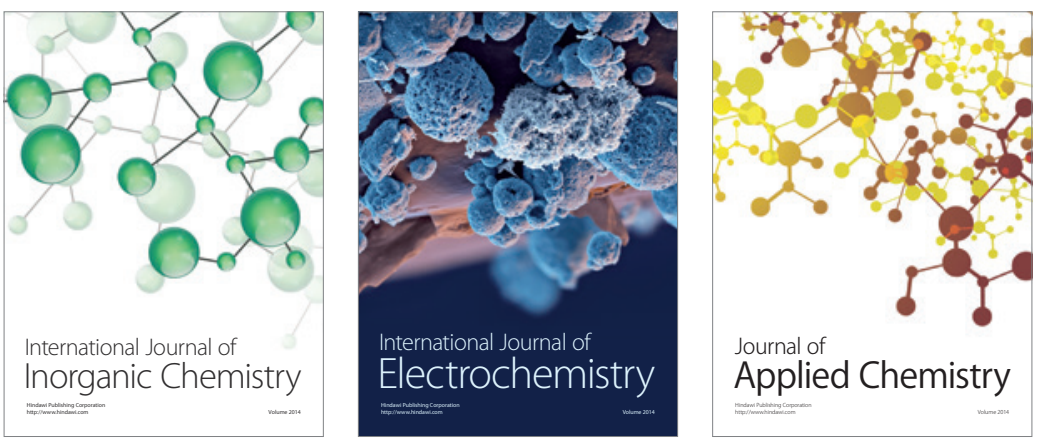

Journal of

Applied Chemistry
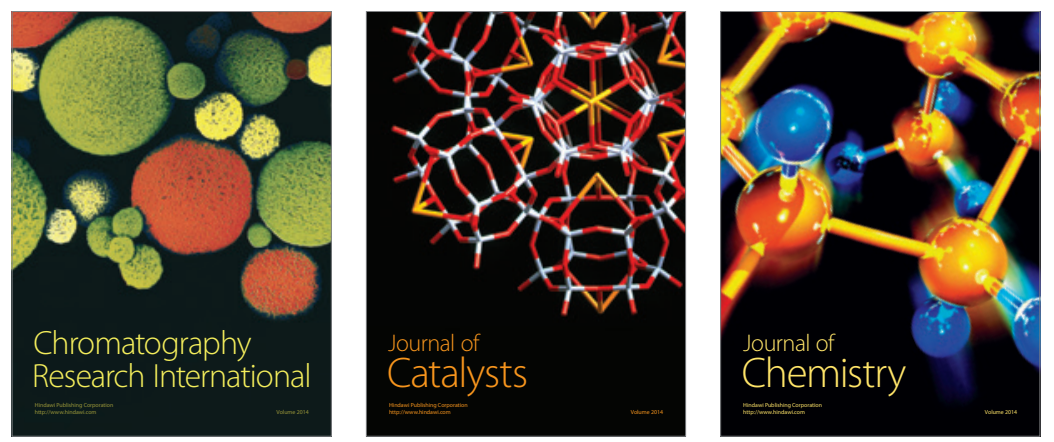
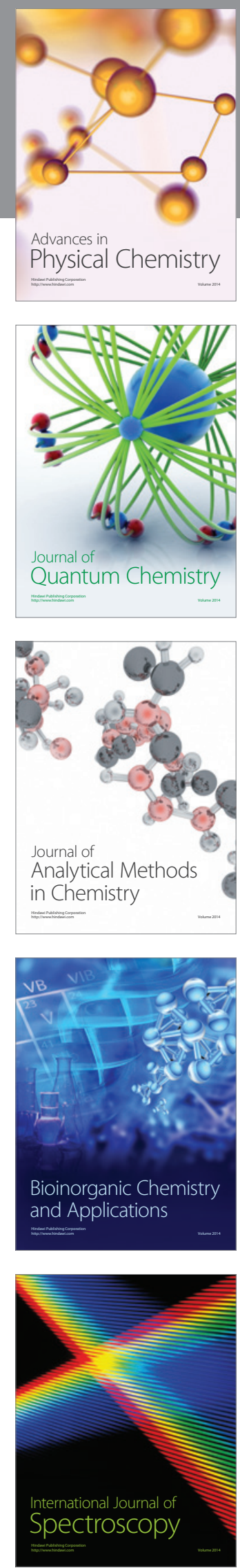